\title{
Analisis Semiotik PidatoPelantikan GubernurDKI Jakarta Anies Baswedan
}

\author{
Sahata Simanjuntak \\ UIN Suka Yogyakarta \\ sahatasimanjuntak2@gmail.com
}

\begin{abstract}
First speech as governor DKI Jakarta was did by Anies Baswedan political communication step to consolidate Jakarta society after DKI Jakarta election. Phrasing content and choosing diction was important things in the formal speech. Phrasing pribumi word was forbidden by law to use, this make blunder for Anies team after contestation with incumbent rival the governor before who was lose, and this make pro and contra in DKI Jakarta society. This research was talked about semiotic analysis using triangle meaning theory Charles Sander Pierce for critic and interpretation descriptify speech governor DKI Jakarta Anies Baswedan content with "pribumi" word was made pro and contra in society life. Anies figure was knowed as an academic who achieved in country and international also served in some strategys position, considered not conscientious phrasing legal speech content ideal was mastered goodly by Anis Baswedan who did good legal speech even without teks. So make some question for researcher how actually content and situation was did speech by Anies. The interpretation of the use of the native word as a sign gives a negative image because it legally violates the president's instructions. But the use of the native word interpreted as an emergency word delivered by Anis represents a sense of injustice experienced by most of the Jakarta community in the context of his speech. This is an indicator that the majority of the people feel the injustice of their rivals whose note is the previous incumbent.
\end{abstract}

Keyword: Semiotic Analysis, Speech, Pribumi.

\begin{abstract}
Abstrak
Pidato perdana sebagai gubernur DKI Jakarta yang dilakukan oleh Anies Baswedan merupakan langkah komunikasi politik untuk konsolidasi masyarakat Jakarta setelah kemenangannya di pilkada DKI Jakarta. Penyusunan isi dan pemilihan diksi merupakan hal yang sangat penting apalagi dalam acara resmi. Masuknya kata "pribumi" yang secara hukum tidak seharusnya digunakan lagi, menjadi sebuah blunder bagi kubu Anies yang baru saja melakukan kontestasi dengan rivalnya incumbent sebelumnya sehingga menghadirkan sikap pro dan kontra di masyarakat. Penelitian ini membahas tentang analisis semiotika menggunakan teori segitiga makna atau triangle meaning Charles Sander Pierce untuk mengkritisi dan menginterpretasi secara deskriptif pidato gubernur DKI Jakarta Anies Baswedan yang memuat kata "pribumi". Sosok Anis yang selama ini dikenal sebagai akademisi yang menorehkan prestasi nasional dan internasional, bahkan sempat menjabat di berbagai posisi strategis dianggap kurang teliti dalam penyusunan konten
\end{abstract}

Jurnal Dakwah dan Komunikasi

IAIN Curup-Bengkulu | E-ISSN: 2548-3366; P-ISSN: 2548-3293 
pidato resmi yang idealnya telah dikuasai dengan baik oleh tokoh sekaliber Anis Baswedan yang terbiasa menyampaikan pidato tanpa teks sekalipun. Sehingga menghadirkan tanda tanya bagi peneliti bagaimana sebenarnya konten dan konteks pidato yang disampaikan oleh Anies. Interpretasi terhadap penggunaan kata pribumi sebagai sebuah tanda memberikan imej negatif karena secara hukum melanggar instruksi presiden. Namun penggunaan kata pribumi diinterpretasi sebagai emergency word yang disampaikan Anis mewakili rasa ketidak adilan yang dialami oleh sebagian besar masyarakat Jakarta dalam konteks pidatonya, terbukti Anis dapat menumbangkan petahana yang dianggap lebih pro kepada asing dan aseng khususnya terkait penggusuran dan reklamasi teluk Jakarta. Hal tersebut menjadi indikator bahwa mayoritas masyarakat merasakan ketidak adilan dari rivalnya yang notabenenya adalah petahana sebelumnya.

Kata Kunci: Analisis Semiotika, Pidato, Pribumi.

\section{Pendahuluan}

Seiring berjalannya waktu perkembangan teknologi komunikasi dan informasi telah begitu pesat. Berbagai penemuan dan produk diteliti dan dihasilkan demi pengembangan berbagai bidang dan disiplin ilmu untuk meningkatkan kualitas hidup masyarakat modern. Saya sebagai akademisi dan praktisi yang berkiprah dalam komunikasi dan penyiaran Islam perlu kiranya melakukan modernisasi dan inovasi untuk mencapai hasil yang efektif.Pengembangan dalam metode, media dan isi sangat diperlukan untuk optimalisasi komunikasi dan penyiaran Islam.

Aktivitas pidato politik gubernur DKI Jakarta Anies Rasyid Baswedan menyita perhatian publik dan menjadi kajian hangat. Anies yang dikenal sebagai akademisi berprestasi nasional dan internasional, pernah menduduki berbagai posisi strategis menuliskan kata "pribumi" dalam pidato resmi perdananya. Padahal penggunaan kata pribumi telah dilarang dalam instruksi presiden nomor 26 tahun 1998 tentang menghentikan penggunaan istilah pribumi dan non pribumi dalam semua perumusan dan penyelenggaraan kebijakan, perencanaan program, ataupun pelaksanaan kegiatan penyelenggaraan pemerintah sehingga menimbulkan pro dan kontra di masyarakat terkait hal tersebut. Maka peneliti memutuskan perlu kiranya upaya untuk menganalisis dan mengkritisi pidato tersebut.

Tulisan ini berusaha menjawab bagaimanakah model analisis semiotika menggunakan teori segitiga makna atau triangle meaning theory Charles Sander Pierce digunakan untuk mengkritisi pidato serah terima jabatan gubernur DKI Jakarta Anies Rasyid Baswedan?. Tujuan Penelitian yang ingin dicapai adalah untuk mengkritisi dan menginterpretasi secara desriptif teks pidato serah terima jabatan gubernur DKI Jakarta Anies Rasyid Baswedan dengan model analisis semiotika menggunakan teori segitiga makna atau triangle meaning theory Charles Sander Pierce.

Adapun kegunaan dari penelitian ini diantaranya adalah sebagai manfaat teoritis dimaksudkan penelitian ini berkontribusi terhadap pengembangan ilmu pengetahuan, modernisasi, inovasi serta gagasan ilmiah bagi komunikasi dan penyiaran Islam. Diharapkan pemanfaatan teori-teori komunikasi untuk membedah dan mengidentifikasi serta mengkritisi pidato serah terima jabatan gubernur DKI Jakarta Anies Rasyid Baswedan. Manfaat praktis dari penelitian ini agar menjadi 
tambahan referensi bagi para pembaca, penikmat, pecinta, penulis teks pidato dalam memperluas wawasannya terkait pidato gubernur DKI Jakarta Anies Rasyid Baswedan. Penelitian ini juga diharapkan berkontribusi untuk melahirkan pidato yang lebih baik lagi demi terbentuknya pribadi muslim yang kaffah dan terwujudnya Islam yang rahmatan lil 'alamin.

\section{Landasan Teori dan Konsep}

\section{a. Semiotika}

Amir Yasraf Piliang menyampaikan pendapat Umberto Eco yang mengatakan, bahwa semiotika “....pada prinsipnya adalah sebuah disiplin yang mempelajari segala sesuatu yang dapat digunakan untuk berdusta (lie)". ${ }^{1}$ Defenisi Eco ini meskipun mungkin sangat mencengangkan banyak orang secara eksplisit menjelaskan betapa sentralnya konsep dusta di dalam wacana semiotika, sehingga dusta tampaknya menjadi prinsip utama semiotika itu sendiri. Sedangkan Ferdinand De Saussure dikutip Amir Yasraf Piliang dalam Course in General Linguistics adalah "ilmu yang mempelajari peran tanda sebagai bagian dari kehidupan sosial". ${ }^{2}$ Semiotika adalah ilmu yang mempelajari struktur, jenis, tipologi, serta relasi-relasi tanda dalam penggunaannya di masyarakat. Oleh sebab itu, semiotika mempelajari relasi di antara komponen-komponen tersebut dengan masyarakat penggunanya. Dalam hal ini, ada berbagai prinsip yang sangat mendasar pada pemikiran Saussure mengenai teori semiotika yakni: prinsip struktural, kesatuan, konvensional, sinkronik, representasi, dan kontinuitas.

Semiotika menurut Amir Yasraf Piliang adalah sebuah cabang keilmuan yang memperlihatkan pengaruh semakin penting sejak empat dekade yang lalu, tidak saja sebagai metode kajian (decoding), akan tetapi juga sebagai metode penciptaan (encoding). ${ }^{3}$ Amir Yasraf Piliang meyampaikan semiotika telah berkembang menjadi model atau paradigma bagi berbagai bidang keilmuan yang sangat luas, yang menciptakan cabang-cabang semiotika khusus, diantaranya adalah semiotika binatang (zoo semiotics), semiotika kedokteran (medical semiotics), semiotika arsitektur, semiotika seni, semiotika fashion, semiotika film, semiotika sastra, semiotika televisi, dan termasuk semiotika desain. ${ }^{4}$ Amir Yasraf Piliang menyampaikan metode semiotika pada dasarnya bersifat kualitatif-interpretatif (interpretation), yaitu metode yang memfokuskan dirinya pada tanda dan teks sebagai objek kajiannya, serta bagaimana peneliti menafsirkan dan memahami kode (decoding) di balik tanda dan teks tersebut. ${ }^{5}$ Metode analisis teks adalah salah satu dari metode interpretatif tersebut. Akan tetapi, sebagaimana dapat dilihat nanti, ada metode-metode yang merupakan perluasan dari metode semiotika,

${ }^{1}$ Yasraf Amir Piliang, Semiotika dan Hipersemiotika, Kode Gaya dan Matinya Makna (Bandung: Matahari, 2010), 44.

${ }^{2}$ Ibid., 46-48.

${ }^{3}$ Ibid., 299.

${ }^{4}$ Ibid., 313.

${ }^{5}$ Ibid., 314. 
yang bersifat lebih kualitatif-empiris, yang memfokuskan dirinya pada subjek pengguna teks (pembaca, penonton, pemakai).

Amir Yasraf Piliang menyebutkan metode semiotika pada dasarnya beroperasi pada dua jenjang analisis. Pertama, analisis tanda secara individual, misalnya jenis tanda, mekanisme atau struktur tanda, dan makna tanda secara individual. Kedua, analisis tanda sebagai sebuah kelompok atau kombinasi, yaitu kumpulan tanda-tanda yang membentuk apa yang disebut sebagai teks. Teks dalam pengertian paling sederhana adalah kombinasi tanda-tanda. Di antara tipologi tanda yang terkenal adalah pengelompokkan tanda menjadi tiga jenis oleh Charles Sanders Pierce, yaitu indeks, ikon dan simbol. Indeks adalah tanda yang hubungan antara penanda dan petanda di dalamnya bersifat kausal, misalnya: hubungan antara asap dan api,. Ikon adalah tanda yang hubungan antara penanda dan petandanya bersifat keserupaan (similitude). Misalnya, foto Soekarno yang merupakan tiruan dua dimensi dari Soekarno. Sementara, simbol adalah tanda yang hubungan penanda dan petandanya bersifat arbiter. ${ }^{6}$

\section{b. Pidato}

Zainul Maarif menyebutkan pidato pada masa sekarang ini dapat disinonimkan dengan oral communication (komunikasi lisan), public communication (komunikasi publik) dan retorika. Retorika berasal dari bahasa Yunani, yaitu rhetorikos artinya kecakapan berpidato. Kata tersebut terkait dengan kata rhetor yang berarti pembicaraan publik, dan terkait dengan kata rhema yang berarti perkataan. ${ }^{7}$ Sehingga secara etimologis, retorika bisa dikatakan sebagai kecakapan berpidato pembicara publik yang terbiasa berkata-kata. Zainul Maarif menjabarkan sedikitnya ada lima tahapan metodis dalam retorika yang paling terkenal, yaitu inventio (penemuan tema dan argumen), dispositio (penyusunan bahan), elocutio (gaya bahasa), memoria (memori/hafalan bahan pidato), dan pronunciatio (penyampaian pidato). ${ }^{8}$ Kelima tahapan metodis tersebut ditopang oleh tiga faktor, yaitu ethos (faktor meyakinkan pada diri komunikator/pembicara), patos (faktor respons emosional pada komunikan/pendengar) dan logos (faktor isi pesan komunikasi.

Zainul Maarif mengatakan ethos dalam literatur retorika adalah "potensi persuasif pada karakter dan kredibilitas personal pembicara". 9 Secara ethos, kepribadian pembicara menjadi faktor penting dalam kesuksesan beretorika. Siapa yang bicara menentukan efektivitas suatu pembicaraan. Tak sembarangan pembicara dapat diterima dengan baik oleh audien. Hanya pembicara berethos yang dapat dengan mudah diiyakan perkataannya. Zainul Maarif mengutip dari kamus Yunani-Inggris yang disusun Liddel dan Scott menyebutkan beberapa makna pathos, antara lain pengalaman baik atau buruk, kondisi sesuatu, dan emosi jiwa. Di buku Rethorics, Aristotle membahas pathos sebagai persuasi pada emosi pendengar. Artinya, seorang komunikator harus bisa memengaruhi

\footnotetext{
${ }^{6}$ Ibid.

7 Zainul Maarif, Retorika Metode Komunikasi Publik (Jakarta: Rajawali Pers), 2015, 1.

${ }^{8}$ Ibid., 3.

${ }^{9}$ Ibid., 9.
} 
emosi komunikan, dengan mengenal emosi pendengar lantas merekayasanya. ${ }^{10}$ Logos adalah kata dalam bahasa Yunani yang berarti kata atau pikiran Zainul Maarif. Logos yang disepadankan dengan kata menderivasikan beberapa makna antara lain janji, pernyataan, resolusi, perintah, ucapan, wacana, dialog, berita, cerita, tulisan, prinsip dan orasi. Logos yang disinonimkan dengan pikiran memiliki beberapa makna juga seperti: opini, harapan, penilaian, dan pertimbangan. ${ }^{11}$

\section{c. Pribumi}

Pribumi dikutip dari https://kbbi.web.id/pribumi, dalam kamus besar bahasa Indonesia /pri $\cdot \mathrm{bu} \cdot \mathrm{mi} / \mathrm{n}$ penghuni asli; yang berasal dari tempat yang bersangkutan; mempribumikan/ mem·pri·bu·mi kan/ $v$ menjadikan milik pribumi. ${ }^{12}$ Pribumi dalam wikipedia adalah setiap orang yang lahir di suatu tempat, wilayah atau negara, dan menetap di sana dengan status orisinal, asli atau tulen (indigenious) sebagai kelompok etnis yang diakui sebagai suku bangsa bukan pendatang dari negeri lainnya. Pribumi bersifat autochton (melekat pada suatu tempat).Secara lebih khusus, istilah pribumi ditujukan kepada setiap orang yang terlahir dengan orang tua yang juga terlahir di suatu tempat tersebut.

Jadi penggunaan kata "pribumi" merujuk kepada status etnis sebagai suatu suku bangsa bukan pendatang dari negeri lainnya sehingga penggunaanya lebih kepada penamaan penduduk secara geografis. Namun kemudian kita melihat pemakaian kata "pribumi" memiliki muatan politis yang kuat yang mempersatukan masyarakat asli Indonesia ketika melawan kolonialisme. Dalam masa kolonial Belanda, pribumi dipakai sebagai istilah bahasa Melayu untuk inlanders, salah satu kelompok penduduk Hindia Belanda yang berasal dari sukusuku asli Kepulauan Nusantara.Oleh karena itu, penduduk Indonesia keturunan Cina, India, Arab (semuanya dimasukkan dalam satu kelompok, Vreemde Oosterlingen), Eropa, maupun campuran sering dikelompokkan sebagai non"pribumi" meski telah beberapa generasi dilahirkan di Indonesia.

Jika dianalisis lebih lanjut kata pribumi merupakan salah satu alat yang digunakan oleh kolonialisme untuk melancarkan politik devide et impera, dimana pengkotak-kotakan telah sukses menghantarkan mereka berkuasa ratusan tahun lamanya di Nusantara. Pengelompokan ini dalam ide tidak rasistis, karena dapat terjadi perpindahan dari satu kelompok ke kelompok lain, tetapi dalam praktik menjadi rasistis karena terjadi pembedaan penempatan dalam publik, perbedaan pengupahan/penggajian, larangan penggunaan bahasa belanda untuk kelompok tertentu, dan sebagainya. Diskriminasi dan praktik rasis dari kata pribumi memiliki konotasi negatif dalam implementasinya di masa penjajahan kolonialisme. Sehingga menimbulkan semangat perlawanan untuk memperjuangkan persamaan kewajiban dan hak, melepaskan diri dari penjajahan di atas dunia. Namun di era kemerdekaan sekarang nama "pribumi" atau inlanders membuka celah terjadinya disintegrasi dalam kehidupan berbangsa dan

\footnotetext{
${ }^{10}$ Ibid., 25.

${ }^{11}$ Ibid., 43.

12 https://kbbi.web.id/pribumi.
} 
bernegara. Sehingga pada masa pemerintahan B.J. Habibie mengeluarkan Instruksi Presiden terkait kata "pribumi".

Aturan tersebut tertuang dalam Instruksi Presiden Nomor 26 Tahun 1998 tentang Menghentikan Penggunaan Istilah Pribumi dan Non Pribumi dalam Semua Perumusan dan Penyelenggaraan Kebijakan, Perencanaan Program, Ataupun Pelaksanaan Kegiatan Penyelenggaraan Pemerintah.Pertimbangan Inpres tersebut dikeluarkan adalah untuk persamaan hak secara hukum dan kehidupan sosial."Menimbang: bahwa untuk lebih meningkatkan perwujudan persamaan kedudukan di dalam hukum dan pemerintahan, persamaan hak atas pekerjaan dan penghidupan, hak dan kewajiban warga negara, dan perlindungan hak asasi manusia, serta lebih memperkokoh persatuan dan kesatuan bangsa, dipandang perlu memberi arahan bagi upaya pelaksanaannya," bunyi pertimbangan Inpres tersebut. Pertama, "Menghentikan penggunaan istilah pribumi dan Non pribumi dalam semua perumusan dan penyelenggaraan kebijakan, perencanaan program, ataupun pelaksanaan kegiatan penyelenggaraan pemerintahan."

\section{Metodologi Penelitian}

Metode adalah cara atau tehnik yang dapat digunakan untuk riset atau penelitian. Metode pengkajian yang digunakan dalam penelitian ini adalah pendekatan kualitatif dengan metode riset semiotika menggunakan model analisis Charles Sanders Peirce. Sedangkan tipe penelitian ini menggunakan tipe metode riset deskriptif. Metode mengatur langkah-langkah dalam melakukan riset atau penelitian dikutip dari Rachmat Kriyantono. ${ }^{13}$ Langkah-langkah yang diambil dalam metode penelitian antara lain:

1. Jenis Penelitian

Mestika Zed menyatakan penelitian ini merupakan penelitian kepustakaan (library research). ${ }^{14}$ Riset kepustakaan ini meliputi pengumpulan data pustaka, membaca, mencatat, dan mengolah bahan penelitian, artinya peneliti berhadapan dengan informasi tetap.

2. Subyek dan Obyek Penelitian

Tatang M. Arifin menyatakan subyek penelitian adalah sumber data dari penelitian. ${ }^{15}$ Maka sumber dimana data itu diperoleh dalam penelitian ini adalah situs liputan6.com.

Hamidi menyebutkan obyek penelitian adalah konsep atau kata-kata kunci yang diteliti yang memiliki kriteria tertentu. ${ }^{16}$ Dalam penelitian ini obyek penelitian adalah pidato gubernur DKI Jakarta Anis Rasyid Baswedan.

${ }^{13}$ Rachmat Kriyantono, Teknik Praktis Riset Komunikasi Disertai Contoh Praktis Riset Media, Public Relation Advertising, Komunikasi Organisasi, Komunikasi Pemasaran Jakarta: Kencana, 2007), 84.

${ }^{14}$ Mestika Zed, Metode Penelitian Kepustakaan (Jakarta: Yayasan Obor Indonesia, 2014), 3.

15 Tatang M. Arifin, Menyusun Rencana Penelitian (Jakarta: Raja Grafika Persada, 1995), 92-93.

${ }^{16}$ Hamidi, Metode Penelitian dan Teori Komunikasi ( Malang: UMM Pers, 2010), 5. 
3. Sumber Data

Terdapat dua jenis sumber data yaitu primer dan sekunder. Sumber data primer dan sekunder. Sumber data primer adalah data yang diperoleh langsung dari sumber data. Dalam penelitian ini data primernya adalah pidato gubernur DKI Jakarta Anis Rasyid Baswedan.

4. Tehnik Pengumpulan Data

Dalam usaha pengumpulan data yang dianggap penting dan berkontribusi dengan obyek penelitian. Dalam penelitian ini dokumentasi yang digunakan adalah pidato Anies Baswedan.

5. Analisis Data

Dalam menganalisis tanda, peneliti menggunakan model analisis semiotika Charles Sander Pierce, yaitu dimana semiotika berangkat dari tiga elemen utama, yang disebut Pierce, teori segitiga makna atau triangle meaning sesuai dengan Rachmat Kriyantono.Yakni:

a. Tanda

Adalah sesuatu yang berbentuk fisik yang dapat ditangkap oleh panca indera manusia dan merupakan sesuatu yang merujuk (merepresentasikan) hal lain di luar tanda itu sendiri. Acuan tanda ini disebut objek.

b. Acuan Tanda (Objek)

Adalah konteks sosial yang menjadi referensi dari tanda atau sesuatu yang dirujuk tanda.

c. Pengguna Tanda (Interpretant)

Konsep pemikiran dari orang yang menggunakan tanda dan menurunkannya ke suatu makna tertentu atau makna yang ada dalam benak seseorang tentang objek yang dirujuk sebuah tanda. ${ }^{17}$

Hubungan Tanda, Objek, dan Interpretan (Triangle of Meaning)

\section{Sign}
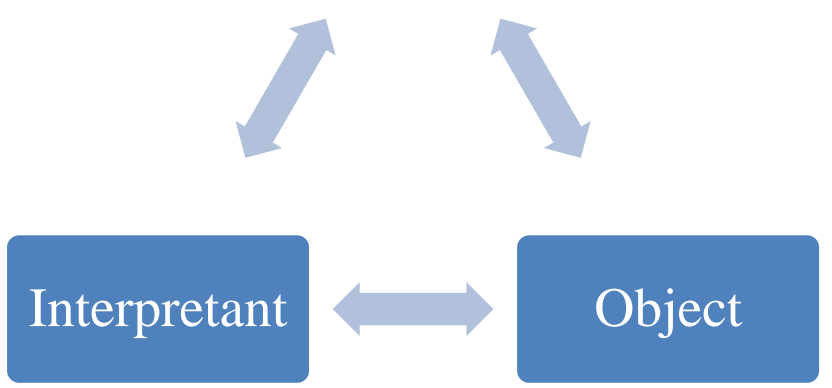

${ }^{17}$ Rachmat Kriyantono, Ibid., 265. 
108 Jurnal Dakwah dan Komunikasi, Vol. 3 No. 2, 2018

Triangle Meaning dalam Pidato gubernur DKI Jakarta Anis Rasyid Baswedan

\section{Sign}

Pidato gubernur DKI Jakarta Anis Rasyid Baswedan

Interpretant

Sikap dan pola pemikiran

Anis Rasyid Baswedan sebagai gubernur

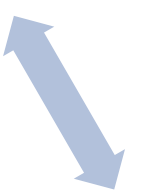

Object

Etos, logos, pathos

Yang dikupas teori segitiga adalah persoalan bagaimana makna muncul dari sebuah tanda ketika tanda itu digunakan orang pada waktu berkomunikasi. Hubungan antara tanda, objek, dan interpretant sebagaimana gambar di atas.

\section{Hasil Penelitian dan Pembahasan}

\section{a. Profil Anies Rasyid Baswedan}

Nama Lengkap
Lahir
Agama
Orang Tua
Saudara
Ridwan Rasyid Baswedan
Istri
Anak

Riwayat Pendidikan
: Anies Rasyid Baswedan

: 7 Mei 1969, di Kuningan, Jawa Barat

: Islam

: Rasyid Baswedan (Ayah) / Aliyah Rasyid (Ibu)

: Abdillah Rasyid Baswedan

: Fery Farhati Ganis

: Mutiara Annisa Baswedan

Mikail Azizi Baswedan

Kaisar Hakam Baswedan

Ismail Hakim Baswedan

: TK Masjid Syuhada

SD Laboratori Yogyakarta

SMP Negeri 5 Yogyakarta.

SMAN 2 Yogyakarta

Universitas Gadjah Mada 
Riwayat Pekerjaan

University of Maryland, College Park

University Northern Illinois

: Peneliti di PAU Studi Ekonomi UGM

Manajer Riset IPC, Inc, Chicago, Amerika Serikat

Direktur Riset Indonesian Institute Center

Rektor Paramadina (2007-2015)

Menteri Pendidikan dan Kebudayaan (2014-

2016)

Gubernur DKI Jakarta (2017-

Penghargaan Anies Baswedan

- $\quad$ The Golden Awards Rakyat Merdeka

- $\quad$ Anugerah Integritas Nasional

- $\quad$ Dompet Dhuafa Award 2013

- Anugerah Hari Sastra Indonesia

- Gerald Maryanov Award

- 100 Intelektual Publik Dunia

- $\quad$ Young Global Leaders

- 20 Tokoh Pembawa Perubahan Dunia

- PASIAD Education Award

- Nakasone Yasuhiro Award

- 500 Muslim Berpengaruh di Dunia

\section{b. Retorika Semiotik Pidato}

Pidato Anies Rasyid Baswedan disampaikan di halaman Balai Kota, Jalan Medan Merdeka Selatan, Jakarta Pusat, Senin, 16 Oktober 2017. Anies berpidato setelah serah terima jabatan. Pidato Anies berlangsung selama 22 menit. Dalam pidatonya, Anies mengutip beberapa pepatah dari berbagai daerah di Indonesia dan juga melemparkan pantun.

Berikut isi pidato lengkap Gubernur DKI Anies Baswedan:

Bismillabirrabmaanirrabiim. Alhamdulillabi rabbil alamin. Washolatu wassalamu 'ala asrofil ambiya iwal mursalin wa'ala alibi wasobbibi aj ma'in. Amma ba'du.

Saudara-saudara semua warga Jakarta.

Assalamu'alaikum Warahmatullahi Wabarakatuh. Salam sejahtera. Om swastiastu. Namo buddhaya.

Saudara-saudara semua, hari ini satu lembar baru kembali terbuka dalam perjalanan panjang Jakarta. Ketika niat yang lurus, ikhtiar gotong-royong dalam makna yang sesungguhnya, didukung dengan doa-doa yang kita terus 
bersama panjatkan, maka pertolongan dan ketetapan Allah SWT itu telah datang.

Tidak ada yang bisa menghalangi apa yang telah ditetapkan oleh-Nya, dan tidak ada pula yang bisa mewujudkan apa yang ditolak oleh-Nya. Warga Jakarta telah bersuara dan terpaut dengan satu rasa yang sama: Keadilan bagi semua. Mari kita terus panjatkan syukur dan doa keselamatan kepada Allah SWT, Yang Maha Menolong dan Maha Melindungi.

Hari ini sebuah amanat besar telah diletakkan di pundak kami berdua. Sebuah amanat yang harus dipertanggungjawabkan dunia akhirat. Hari ini adalah penanda awal perjuangan dalam menghadirkan kebaikan dan keadilan yang diharapkan seluruh Rakyat Jakarta, yaitu kemajuan Ibu Kota tercinta dan kebahagiaan seluruh warganya.

Hari ini, saya dan Bang Sandi dilantik menjadi gubernur dan wakil gubernur bukan bagi para pemilih kami saja, tapi bagi seluruh warga Jakarta. Kini saatnya bergandengan sebagai sesama saudara dalam satu rumah untuk memajukan kota Jakarta.

"Holong manjalak holong, holong manjalak domu," demikian sebuah pepatah Batak mengungkapkan. Kasih sayang akan mencari kasih sayang, kasih sayang akan menciptakan persatuan. Ikatan yang sempat tercerai, mari kita ikat kembali. Energi yang sempat terbelah, mari kita satukan kembali.

Jakarta adalah tempat yang dipenuhi oleh sejarah. Setiap titik Jakarta menyimpan lapisan kisah sejarah yang dilalui selama ribuan tahun. Jakarta tidak dibangun baru-baru saja dari lahan hampa. Sejak era Sunda Kalapa, Jayakarta, Batavia hingga kini, Jakarta adalah kisah pergerakan peradaban manusia.

Jakarta sebagai melting pot telah menjadi tradisi sejak lama. Di sini tempat berkumpulnya manusia dari penjuru Nusantara, dan penjuru dunia. Jakarta tumbuh dan hidup dari interaksi antar-manusia.

Dalam sejarah panjang Jakarta, banyak kemajuan diraih dan pemimpin pun datangsilih berganti. Masing-masing meletakkan legasinya, membuat kebaikan danperubahan demi kota dan warganya. Untuk itu kami sampaikan apresiasi dan rasa terima kasih kepada para Gubernur dan Wakil Gubernur sebelumnya, yang turutmembentuk dan mewarnai wujud kota hingga saat ini.

Jakarta juga memiliki makna pentingnya dalam kehidupan berbangsa. Di kota ini, tekad satu tanah air, satu bangsa dan satu bahasa persatuan ditegakkan oleh parapemuda. Di kota ini pula bendera pusaka 
dikibartinggikan, tekad menjadi bangsa yang merdeka dan berdaulat diproklamirkan ke seluruh dunia.

Jakarta adalah satu dari sedikit tempat di Indonesia yang merasakan hadirnya penjajah dalam kehidupan sehari-hari selama berabad-abad lamanya. Rakyat pribumi ditindas dan dikalahkan oleh kolonialisme. Kini telah merdeka, saatnya kita jadi tuan rumah di negeri sendiri.

Jangan sampai terjadi di Jakarta ini apa yang dituliskan dalam pepatah Madura, "Itikse atellor, ajam se ngeremme." Itik yang bertelur, ayam yang mengerami. Seseorang yang bekerja keras, hasilnya dinikmati orang lain.

Kini kami datang untuk melanjutkan segala dasar kebaikan yang telah diletakkan para pemimpin sebelumnya, sembari memperjuangkan keberpihakan yang tegas kepada mereka yang selama ini terlewat dalam merasakan keadilan sosial, membantu mengangkat mereka yang terhambat dalam perjuangan mengangkat diri sendiri, serta membela mereka yang terugikan dan tak mampu membela diri.

Jakarta adalah ibukota Negara Kesatuan Republik Indonesia, maka selayaknya ia menjadi cermin dan etalasi dari semangat NKRI, semangat Pancasila dan semangat tegaknya konstitusi.

Di kota ini lah Pancasila harus mengejawantah, setiap silanya harus mewujud menjadi kenyataan. Dimulai dari hadirnya suasana ketuhanan dalam setiap sendi kehidupan kota.

Indonesia bukanlah negara yang berdasar satu agama, namun Indonesia juga bukan negara sekuler. Ketuhanan, selayaknya menjadi landasan kehidupan warga. Prinsip ketuhanan ini kemudian harus diwujudkan pula dengan hadirnya rasa kemanusiaan dan keadilan bagi seluruh rakyat, tanpa ada yang terpinggirkan, terugikan, apalagi tidak dimanusiakan dalam kehidupannya.

Perjuangan selanjutnya adalah memperjuangkan persatuan dalam kehidupan kota, tak hanya merayakan keragaman. Ada sebuah pepatah Aceh yang bermakna, "Cilakarumah tampa atap, cilaka kampung tanpa guyub." Persatuan dan keguyuban ini yang harus terus kita perjuangkan, dimulai dari meruntuhkan sekat-sekat interaksi antarsegmen masyarakatnya, terutama pemisahan ruang interaksi berdasar kemampuan ekonomi.

Dalam mewujudkan semua prinsip itu, dialog dan musyawarah harus diutamakan melalui mekanisme majelis-majelis perwakilan warga yang dilibatkan dalam setiap pengambilan kebijakan. Musyawarah diutamakan untuk menghasilkan kesepakatan dan kesepahaman. 
"Tuah sakato," kata orang Minang. Dalam kesepakatan berdasar musyawarah itu terkandung tuah kebermanfaatan. Dan di ujungnya, namun menjadi yang terpenting, kita perjuangkan hadirnya keadilan sosial bagi seluruh rakyat Jakarta. Karena hadirnya keadilan sosial ini akan menjadi parameter utama terwujudnya semangat Pancasila di kota ini.

Seluruh aspek dan alat pembangunan kota haruslah ditujukan untuk menghadirkan keadilan sosial bagi warga. Termasuk APBD, jelas harus mencerminkan keberpihakan kepada mereka yang belum merasakan keadilan sosial.

Bung Karno dahulu berucap, "Kita hendak membangun satu negara untuk semua. Bukan buat satu orang, bukan buat satu golongan, baik golongan bangsawan maupun golongan yang kaya, tapi semua untuk semua." Maka segala pengambilan kebijakan di kota ini haruslah didasarkan pada kepentingan publik luas.

Pengelolaan tanah, air, teluk dan pulau, tidaklah boleh diletakkan atas dasar kepentingan suatu individu, kepentingan suatu golongan, kepentingan suatu perhimpunan, ataupun kepentingan suatu korporasi. Semua untuk semua, Jakarta untuk semua, inilah semangat pembangunan yang akan kita letakkan untuk Jakarta.

Jakarta adalah saksi bagaimana sebuah bangsa menempuh jalan terjal mendaki untuk wujudkan mimpi merdekanya. Tanggung jawab kita kini adalah menjadikan Ibukota menjadi kota milik semua. Setiap keluarga dan pribadi kita harus bisa mengatakan dengan penuh rasa syukur, beruntung kita tinggal di Ibukota.

Ibu kota harus menjadi kota yang manusiawi, kota yang memberikan ruang pada seni, kebudayaan dan tradisi untuk berkembang, sekaligus kota yang kehidupannya membahagiakan.

Di ibukota semua harus berkesempatan untuk maju bersama. Jakarta harus Maju Bersama. Gubernur dan Wakil Gubernur tentu menjadi pemimpin bagi semua dan harus menghadirkan keadilan bagi semua.

Namun jelas pula bahwa kami hadir dengan tekad mengutamakan pembelaan yang nyata kepada mereka yang selama ini tak mampu membela diri sendiri, membantu mengangkat mereka yang selama ini terhambat dalam perjuangan mengangkat diri sendiri.

Bang Sandi tadi sudah menegaskan komitmen dan paradigma ke depan tentang pembangunan kota. Bang Sandi sudah jabarkan bagaimana kita akan bersama-sama membangun dan mengelola kampung, jalan, sekolah, puskesmas, pasar, angkot, dan berbagai aspek kota lainnya. 
Seperti kata Bang Sandi, ini adalah satu langkah bersama ke depan, memastikan Jakarta yang lebih ramah mimpi. Untuk itu, kami hadir mengajak seluruh warga, menjadikan usaha memajukan kota sebagai sebuah gotong royong, sebuah gerakan bersama.

Dalam pembangunan kota ke depan, Gubernur bukan sekadar administrator bagi penduduk kota, bukan pula sekadar penyedia jasa bagi warga sebagai konsumennya. Namun kami bertekad akan menjadi pemimpin bagi kolaborasi warga kota yang berdaya dan turut menjadi perancang dan pelaku pembangunan.

Dalam pepatah Banjar dikatakan, "Salapik sakaguringan, sabantal sakalang gulu." Satu tikar tempat tidur, satu bantal penyangga leher. Kiasan ini bermakna hubungan antar elemen masyarakat yang erat, saling setia dan mendukung satu sama lain.

Inilah semangat yang hendak kita bangun. Selain itu, kami mengajak pula seluruh elemen kepemimpinan di kota Jakarta ini, mulai dari jajaran pemerintah daerah, para wakil rakyat, pemimpin lembaga pertahanan, keamanan dan penegakan hukum, untuk memiliki tekad yang sama: menghibahkan hidupnya kepada rakyat Jakarta, bukan sebaliknya, menyedot kekayaan dari kota dan warganya, untuk dibawa pulang ke rumahnya.

Sebuah kearifan lokal dari Minahasa mengingatkan, "Si tou timou tumou tou." Manusia hidup untuk menghidupi orang lain, menjadi pembawa berkah bagi sesama. Sebuah pengingat bagi semua manusia, namun terutamanya bagi para pemimpin.

Mohammad Husni Thamrin, seorang putra terbaik Jakarta pernah mengatakan: "Setiap pemerintah harus mendekati kemauan rakyat. Inilah sepatutnya dan harus menjadi dasar untuk memerintah. Pemerintah yang tidak mempedulikan atau menghargakan kemauan rakyat sudah tentu tidak bisa mengambil aturan yang sesuai dengan perasaan rakyat."

Ucapan Husni Thamrin ini terpatri dalam patungnya yang berdiri di Lapangan Monas di hadapan kita ini.

Saudara-saudara semua, perjuangan kita ke depan adalah perjuangan untuk mewujudkan gagasan, kata dan karya yang selama ini telah kita tekadkan. Dengan tak henti memohon pertolongan kepada Yang Maha Memberi Pertolongan, mari kita bersama berikhtiar mewujudkan Jakarta yang maju setiap jengkalnya, dan bahagia setiap insan di dalamnya.

Tanah Air Indonesia adalah karunia Allah. Ciptaan Tuhan yang Maha Pengasih dan Maha Penyayang. Bangsa ini diberikan keindahan dan 
kekayaan Alam yang tiada tandingnya. Ya, alam Indonesia adalah ciptaan Tuhan, tapi desa, kota dan negara di tanah ini adalah ciptaan manusia.

Tuhan menciptakan alam, manusia membentuk kota. Bagaimana kota kita sepenuhnya kembali pada diri kita semua. Semoga Allah SWT membantu ikhtiar kita, melindungi ibukota, menjadikannya wilayah yang baldatun thayyibatun wa rabbun ghafur, serta menurunkan keberkahan bagi setiap warganya.

Laa hawla wa laa quwwata illa billah. Tiada usaha, kekuatan,dan daya upaya selain dengan kehendak Allah. Wallahu muwafiq ila aqwamith thoriq, billahi taufiq wal hidayah. Wassalamu'alaikum Wr. Wb.

Tabel. 1. Representasi Pluralis Lead Pidato

\begin{tabular}{|l|l|l|l|}
\hline No & Tanda & Objek & Interpretan \\
\hline 1 & \multirow{3}{*}{ Religius } & Basmalab & Islam \\
\cline { 4 - 4 } 2 & & Hamdalah & Islam \\
\cline { 3 - 4 } & & Salam & Islam \\
\cline { 3 - 4 } & & Om swasti & Hindu \\
\hline 4 & & Namo Buddhaya & Budha \\
\hline 5 & & \multicolumn{2}{|l}{} \\
\hline \multicolumn{2}{|l|}{ Representasi: Nilai Pluralis } \\
\hline
\end{tabular}

Pidato dibuka dengan basmalah dan hamdalah sebagai tanda kesyukuran kepada Allah, selanjutnya shalawat dan salam kepada Rasulullah. Sapaan kepada semua audiens dalam bahasa yang akrab menggunakan kata saudara sebagai bentuk kedekatan kepada para audiens khususnya yang berdomisili di DKI Jakarta. Salam pembuka merupakan do'a keselamatan dan keberkatan, kesejahteraankepada audiens. Salam Om Swastyastu istilah sakral sebagai sebutan atau seruan pada Tuhan Yang Maha Esa. Kemudian pujian kepada budha.

Tabel 2. Representasi Filosofis Body Pidato

\begin{tabular}{|c|c|c|c|}
\hline No & Tanda & Objek & Interpretan \\
\hline 1 & \multirow{7}{*}{ Multikulturalis } & $\begin{array}{l}\text { "Holong manjalak holong, bolong } \\
\text { manjalak domu" }\end{array}$ & Pepatah Batak \\
\hline 2 & & "Itikse atellor, ajam se ngeremme" & Pepatah Madura \\
\hline 3 & & $\begin{array}{l}\text { "Cilakarumah tanpa atap, cilaka } \\
\text { kampung tanpa guyub" }\end{array}$ & Pepatah Aceh \\
\hline 4 & & "Tuah sakato" & Pepatah Minang \\
\hline 5 & & $\begin{array}{l}\text { "Salapik sakaguringan, sabantal } \\
\text { sakalang gulu" }\end{array}$ & Pepatah Banjar \\
\hline 6 & & "Si tou timou tumou tou" & Pepatah Minahasa \\
\hline 7 & & $\begin{array}{l}\text { "Kita hendak membangun satu } \\
\text { negara untuk semua. Bukan } \\
\text { buat satu orang, bukan buat satu }\end{array}$ & $\begin{array}{l}\text { Perkataan Bung } \\
\text { Karno }\end{array}$ \\
\hline
\end{tabular}




\begin{tabular}{|c|c|c|}
\hline & $\begin{array}{l}\text { golongan, baik golongan } \\
\text { bangsawan maupun golongan } \\
\text { yang kaya, tapi semua untuk } \\
\text { semua" }\end{array}$ & \\
\hline 8 & $\begin{array}{lr}\text { "Setiap pemerintah } & \text { harus } \\
\text { mendekati kemauan rakyat. } & \text { ras } \\
\text { Inilah sepatutnya dan } & \text { harus } \\
\text { menjadi dasar } & \text { untuk } \\
\text { memerintah. Pemerintah yang } & \text { tidak mempedulikan atau } \\
\text { menghargakan kemauan rakyat } \\
\text { sudah tentu tidak bisa } \\
\text { mengambil aturan yang sesuai } \\
\text { dengan perasaan rakyat." }\end{array}$ & $\begin{array}{l}\text { Perkataan } \\
\text { Muhammad } \\
\text { Husni Thamrin }\end{array}$ \\
\hline
\end{tabular}

Sebuah frase yang diambil dari pepatah Batak yang memiliki nilai filosofis representasi dari tenun kebangsaan yang digaungkan Anis, melestarikan bahasa daerah dan kearifan lokal ke tingkat nasional bahkan internasional sebagai bentuk cinta dan bangga akan budaya bangsa Indonesia khususnya warga Batak di DKI Jakarta. Pepatah Madura yang merepresentasikan kearifan lokal yang memiliki nilai filosofis tinggi walaupun telah merdeka tetap harus waspada bekerja dan berdo'a agar apa yang diupayakan dapat dipetik dan bermanfaat untuk kemaslahatan warga Jakarta.

Pepatah yang telah lama menjadi falsafah hidup orang Minang bahwa hasil dari musyawarah yakni kesepakatan bersama memiliki tuah penyatuan visi dan misi yang tentu setiap orang merasa bertanggungjawab dan berkontibusi demi mewujudkannya, termasuk keadilan sosial bagi seluruh rakyat dapat ditunaikan jika dilakukan secara musyawarah untuk mufakat sehingga semua potensi dapat dioptimalkan demi realisasi visi dan misi.

Pemikiran tenun kebangsaan yang coba dirajut oleh Anis dengan mengambil pepatah Banjar, yang tentu merupakan elemen masyarakat yang ada di Jakarta sehingga membangun semangat pembangunan secara bersama saling dukung dan setia demi kesejahteraan dan kebahagiaan bersama. Nilai filosofi Minahasa yang tercermin sangat mendalam bahwa saling mengisi dan menghidupi sebagai bentuk kerja bersama bermanfaat bagi orang lain yang dimaksud pepatah ini bukan malah menjadi pagar makan tanaman atau musuh dalam selimut.

Pemikirannya terkait ucapan Sukarno merefleksikan visi dan misi founding father negeri ini untuk mengarahkan kebijakan secara tepat dan seksama sebab kepentingan publik luas merupakan prioritas dalam upaya mewujudkan kemaslahatan bersama menuju kesejahteraan. Pemikiran Husni Thamrin yang dikutip Anis terkait aspirasi masyarakat dan perumusan aturan serta penegakan rasa keadilan menjadi kunci bagi pemerintah yang ingin bekerja bersama rakyatnya, memahami dan menghargai pendapat demi kemufakatan kerja, yang diharapkan terimplementasi secara riil di tataran praktis. 
Tabel 3. Representasi Optimistis Penutup Pidato

\begin{tabular}{|l|l|l|l|}
\hline No & Tanda & Objek & Interpretan \\
\hline 1 & \multirow{3}{*}{ Visioner } & $\begin{array}{l}\text { "Perjuangan kita ke depan adalah } \\
\text { perjuangan untuk mewujudkan } \\
\text { gagasan, kata dan karya yang } \\
\text { selama ini telah kita tekadkan" }\end{array}$ & Rumusan Visi dan \\
\cline { 3 - 4 } & Do'a & Religius \\
\cline { 3 - 4 } 2 & Salam & Islam \\
\hline 3 & \multicolumn{2}{|l}{} \\
\hline \multicolumn{2}{|l|}{ Representasi: Nilai Optimistis } \\
\hline
\end{tabular}

Sapaan akrab yang digunakan Anis untuk menggugah para audience mengkonsolidasikan niat untuk langkah perjuangan realisasi berbagai mimpi dan harapan masyarakat. Anis menggugah masyarakat untuk berdo'a sebagai bentuk syukur sebab sekuat apapun upaya manusia tanpa keridhoan Allah akan sia-sia belaka, tentu saja demi kemajuan dan kebahagiaan. Pemikiran Anis terkait karunia Allah subhanabu wa ta'alaatas bangsa Indonesia termasuk kemerdekaannya merupakan bentuk kesyukuran hamba, iman dan takwa yang tentu saja harus diimbangi dengan menjaga serta melestarikan ciptaanNya dengan berkarya berkontribusi membangun dengan ilmu pengetahuan dan teknologi memperhatikan dampak yang ditimbulkan.

Anis menekankan sinergi iman dan takwa kepada Allah sebagai pencipta alam semesta serta ilmu pengetahuan dan teknologi praktis guna mendukung pembangunan karena upaya manusia tetap bergantung pada ketetapannya demi menjaga keberlangsungan generasi dan mewujudkan negara yang makmur dan diberkahi oleh Allah subhanahu wa ta'ala. Anis menyampaikan bahwa ketetapan dan kehendak Allah berada di atas segalanya sebagai wujud tawakkal atas berbagai upaya yang telah dilakukan. Hanya Allah jualah yang mampu menuntun ke jalanNya dengan pertolongan dan petunjukNya, ditutup dengan salam, do'a kepada seluruh audience.

\section{c. Pembahasan}

Sapaan keakraban kepada audiens kemudian kalimat penegasan dimulainya sejarah baru kota jakarta, maka dengan dilantiknya Anis-Sandi diharapkan kebersamaan dalam penegasan niat dan iktiar serta upaya dalam berdo'a kepada Allab Subhanabu wa ta'ala sebagai bentuk tawakkal kepadaNya serta mengharap pertolonganNya karena bagaimanapun upaya dalam melakukan sesuatu maka ketetapan Allab Subhanahu wa ta'ala jualah yang berlaku. Suatu bentuk kesyukuran sekaligus tawakkal kepada Allah atas apa yang telah diupayakan hingga akhirnya serah terima jabatan gubernur DKI Jakarta dapat berlangsung baik setelah melalui perjalanan dan perjuangan panjang namun sesungguhnya ini merupakan awal langkah dari Anis - Sandi memimpin DKI Jakarta sehingga beliau meminta agar memanjatkan do’a kepada Allah sebagai wujud kesyukuran dan optimisme

Penekanan peristiwa yang terjadi dengan kata hari ini mengacu kepada tercatatnya lembaran baru bagi warga DKI Jakarta, penegasan terhadap 
integritas keduanya sebagai pemegang amanah yang akan dimintai pertanggung jawabannya oleh negara dan Allah Subhanahu wa ta'ala. Harapan merupakan do'a yang tercetus sebagai langkah baru yang optimis demi DKI Jakarta yang maju kotanya, bahagia warganya.Disini Anis menegaskan kembali pentingnya merekatkan masyarakat Jakarta setelah sebelumnya berkontestasi dalam pilkada, diharapkan setelah pelantikan gubernur baru ini persaudaraan terajut kembali untuk memajukan kota Jakarta. Dan Anis menjanjikan tidak ada diskriminasi terhadap yang tidak memilihnya. Pemikiran Anis mengenai sejarah panjang Jakarta yang menyimpan banyak kisah yang silih berganti pasang surut pembangunan, suka duka perjuangan mengkonstruksi memory Jakarta yang penuh nostalgia yang akan terus bergerak maju untuk membangun peradaban yang akan ditulis tinta sejarah.

Jakarta dengan posisinya yang strategis, didukung manufaktur dan infrastruktur yang lengkap merupakan primadona sejak lama dan menjadi rebutan dari masa ke masa sehingga bermacam budaya berinteraksi dan berkomunikasi melahirkan kota Jakarta yang majemuk dari berbagai latar belakang. Merupakan bentuk penghargaan atas jasa para pahlawan khususnya para gubernur DKI Jakarta sebelumnya yang telah berkontribusi aktif dalam membangun dan memajukan Jakarta menandakan Anis merupakan seorang pemimpin yang berjiwa besar. Pemikirannya secara historis bahwa Jakarta sebagai ikon bangsa Indonesia, berbagai peristiwa dan kejadian penting termaktub dalam sejarah dilakukan di kota Jakarta, sumpah pemuda dan proklamasi kemerdekaan Indonesia sebagai tonggak peristiwa bersejarah menjadikannya begitu berharga

Jakarta dahulu batavia merupakan simbol pusat aktivitas kolonialisme di nusantara selama berabad-abad penjajah mencengkramkan kukunya dari Jakarta, merupakan suatu kesyukuran jika hari ini Jakarta telah merdeka melalui perjuangan panjang dan seyogyanya diisi dengan pembangunan.Terkait dengan pidato politik Gubernur DKI Jakarta Anis Rasyid Baswedan yakni:

"Jakarta adalah satu dari sedikit tempat di Indonesia yang merasakan hadirnya penjajah dalam kehidupan sehari-hari selama berabad-abad lamanya. Rakyat pribumi ditindas dan dikalabkan oleh kolonialisme. Kini telah merdeka, saatnya kita jadi tuan rumah di negeri sendiri".

Jika kita teliti penggunaan kata "pribumi" dalam konteks pidato tersebut merupakan deskripsi Jakarta dimasa lalu untuk memunculkan atmosfer semangat perjuangan melepaskan diri dari penjajahan kolonialisme. Rakyat "pribumi" berpredikat objek merupakan objek penderita penindasan oleh subjek dalam hal ini kolonialisme oleh belanda.

Disini Anis berkomitmen untuk melanjutkan hal baik yang telah dilakukan oleh para pemimpin Jakarta sebelumnya sembari mengevaluasi dan melengkapi apa yang menjadi kekurangan pemimpin di masa lalu untuk solusi yang tepat. Anis menegaskan keberpihakannya kepada wong cilik yang beberapa bulan terakhir merasa terzholimi akibat relokasi dan penggusuran yang dianggap sebagai bentuk neo kolonialisasi. Pemikirannya akan Jakarta sebagai simbol negara merupakan representasi dari Indonesia, sebab segala aktivitas terintegrasi 
dan terinterelasi dengan Jakarta sebagai pusat kuasa dan seyogyanya menjadi role model bagi daerah lainnya.

Pancasila sebagai dasar negara haruslah membumi dan terimplementasikan dalam berbagai aktivitas secara riil dimulai dari aplikasi sila pertama pancasila yang menjadi ruh kegiatan yang berlandaskan ketuhanan yang maha esa. Pemikiran Anis yang pluralis dan toleran tercermin dari frase ini, Indonesia sebagai negara hasil kompromi berbagai latar belakang agama dan budaya harus dapat mengayomi keseluruhan komunitas tersebut dengan adil, prinsip ketuhanan harus didukung rasa kemanusiaan dan keadilan jangan ada diskriminasi dan merasa dianak tirikan demi mewujudkan kesejahteraan. Adapun upaya yang dilakukan untuk merealisasikannya ditempuh dengan dialog dan musyawarah untuk mufakat bentuk kebijaksanaan agar konsolidasi dapat tercipta dengan stakeholder.

Pemikirannya terkait dengan berbagai permasalahan Jakarta khususnya rasa keadilan merupakan suatu hal yang radix, sebab rasa keadilan tak melulu soal materi sebab tak semua bisa dibeli dengan uang. Suatu peletakan visi dan misi yang tegas dan jelas bahwa kepentingan bersama di atas kepentingan kelompok dan golongan, demi tercapainya cita-cita kemerdekaan yang menuju kesejahteraan sosial bagi seluruh masyarakat. Pemikiran Anis yang mengkonstruksi mental audience agar optimis dengan membuka lembar sejarah Jakarta sebagai jembatan untuk pembangunan kini dan kemajuan yang berkesinambungan di masa mendatang. Dan meletakkan rasa syukur dan sabar sebagai bentuk keikhlasan dalam menghadapi berbagai kemungkinan dan resiko dari langkah yang ditempuh.

Disini Anis sepertinya mencoba untuk mendistorsi pameo "ibu kota lebih jahat dari ibu tiri" agar pusat dari aktivitas negara Indonesia ini dapat menjadi kota yang ramah bagi semua aktivitas yang berkontribusi untuk kemaslahatan dan kebahagiaan masyarakatnya. Penegasan akan komitmen bersama gubernur dan wakilnya beserta seluruh jajaran dan instansi terkait untuk bersama dalam upaya memajukan Jakarta dengan tetap menghadirkan rasa keadilan bagi semua. Masyarakat kecil, fakir dan miskin tentu masuk dalam kategori yang disebutkan oleh Anis tersebut namun secara umum Anis hendak menyampaikan siapapun kalian dan apapun profesi kalian kami akan mengupayakan rasa keadilan karena siapapun bisa dilanda ketidakadilan.

Pemikiran Anis tentang wakilnya Sandi yang telah menyampaikan penegasan komitmen dan paradigma pembangunan kota secara teknis sebagai langkah untuk mensolidkan langkah realisasi pembangunan Jakarta bersamasama.

Anis menyampaikan gagasan Sandi yang brilian dan berani untuk bermimpi serta mewujudkannya yang dianggap sebagai representasi formula kerja bersama untuk membangun chemistry gotong-royong yang kuat dan memudahkan di tataran praktis. Pemikiran Anis untuk menggagas konsep kepemimpinan partisipatif yang turut serta dalam memajukan Jakarta dengan kolaborasi berbagai elemen masyarakat merupakan langkah kongkret dari kerja bersama tidak sekedar memberikan instruksi dan kemudian menyalahkan tetapi membimbing kepada kemajuan pembangunan yang berdaulat. Pemikiran Anis tentang semangat komitmen bersama dari seluruh stakeholder untuk bekerja 
dengan tuntas dan ikhlas sebagai langkah nyata dari pengabdian kepada bangsa dan negara khususnya di Jakarta sebagai ladang kerjanya. Mengkritisi langkah kerja oknum stakeholder dan Incumben yang bermental oportunis dan bergaya penjajah hanya memikirkan dirinya sendiri tanpa menghiraukan masyarakat yang kehilangan rasa keadilan.

\section{Kesimpulan}

Secara keseluruhan pidato gubernur DKI Jakarta Anis Rasyid Baswedan mencerminkan sosok pemimpin cerdas multikulturalis dan visioner yang menguasai bahasa dan sejarah, menguasai permasalahan dan mampu mencari solusinya. Hal tersebut didukung juga oleh sisi religiusnya yang selalu melibatkan Allah subhanabu wa ta'ala, mengkombinasikan dunia dan akhirat sebagai dua hal yang seiring sejalan dalam berbagai kesempatan. Hal tersebut menjadi modal besar bagi Anis dalam memenangkan kontestasi politik di DKI Jakarta yang menjadikannya orang nomor satu.

Kata "pribumi"dalam kamus besar bahasa Indonesia /pri·bu·mi/ $n$ penghuni asli; yang berasal dari tempat yang bersangkutan; mempribumikan/ mem·pri·bu·mi kan/ $v$ menjadikan milik pribumi. Instruksi presiden nomor 26 tahun 1998 tentang menghentikan penggunaan istilah pribumi dan non pribumi dalam semua perumusan dan penyelenggaraan kebijakan, perencanaan program, ataupun pelaksanaan kegiatan penyelenggaraan pemerintah telah diatur secara hukum. Sehingga interpretasi terhadap penggunaan kata pribumi sebagai sebuah tanda memberikan imej negatif karena secara hukum melanggar instruksi presiden.

Namun perlu dipahami penggunaannya sebagai objek dalam konteks deskripsi sejarah untuk menghadirkan atmosfer masa lalu sebagai spion menuju masa depan perlu kedewasaan sikap untuk lebih bijaksana memahami dan mengkritisi secara konstruktif sehingga tidak terkesan mencari-cari kesalahan, agar tidak terjadi salah paham kalau tidak mau dikatakan gagal paham. Penggunaan kata pribumi diinterpretasi sebagai emergency word yang disampaikan Anis mewakili rasa ketidak adilan yang dialami oleh sebagian besar masyarakat Jakarta dalam konteks pidatonya, terbukti Anis dapat menumbangkan petahana yang dianggap lebih pro kepada asing dan aseng khususnya terkait penggusuran dan reklamasi teluk Jakarta. Hal tersebut menjadi indikator bahwa mayoritas masyarakat merasakan ketidak adilan dari rivalnya yang notabenenya adalah petahana sebelumnya.

\section{Daftar Pustaka}

Alex, Sobur, Semiotika Komunikasi, Bandung: PT. Remaja Rosdakarya, 2006.

Arikunto,Suharsimi, Prosedur Penelitian Suatu Pendekatan Praktik, Yogyakarta: PT. Rineka Cipta, 1993.

Danesi, Marcel, Pengantar Memahami Semiotika Media, Yogyakarta: Jalasutra, 2010.

Hamidi, Metode Penelitian dan Teori Komunikasi, Malang: UMM Pers, 2010. 
Kriyantono, Rachmat, Teknik Praktis Riset Komunikasi Disertai Contoh Praktis Riset Media, Public Relation Advertising, Komunikasi Organisasi, Komunikasi Pemasaran, Jakarta: Kencana, 2007.

Littlejohn, W. Stephen, Karen A. Foss, Theories of Human Communication, 9th ed diterjemahkan oleh Muhammad Yusuf Hamdan, Jakarta: Salemba, 2009.

M. Arifin,Tatang, Menyusun Rencana Penelitian, Jakarta: Raja Grafika Persada, 1995.

Nawiroh, Vera, Semiotika dalam Riset Komunikasi, Bogor: Penerbit Ghalia Indonesia, 2014.

Yasraf Amir Piliang, Semiotika dan Hipersemiotika, Kode Gaya dan Matinya Makna, Bandung: Matahari, 2010.

Zainul Maarif, Retorika Metode Komunikasi Publik, Jakarta: Rajawali Pers, 2015.

Zed, Mestika, Metode Penelitian Kepustakaan, Jakarta: Yayasan Obor Indonesia, 2014.

\section{Sumber website:}

https://biografiku.com

https://id.wikipedia.org

https://liputan6.com

https://merdeka.com

https://republika.com

Ucapan Terima Kasih: 